\title{
Ozonation of pentylacetate contaminated waters from textile care industry
}

\section{Ozonización de aguas contaminadas con pentilacetato de la industria de limpieza en seco de textiles}

Fecha de entrega: 13 de junio 2012

Fecha de aceptación: 3 de abril 2013

\section{Héctor Valdés ${ }^{1}$, Klaus Schrickel², Hinnerk Bormann ${ }^{3}$ and Michael Sievers $^{3}$}

${ }^{1}$ Laboratorio de Tecnologías Limpias, Facultad de Ingeniería, Universidad Católica de la Santísima Concepción, Alonso de Ribera 2850, Casilla 297, Concepción, Chile, hvaldes@ucsc.cl

${ }^{2}$ Thermo Electron GmbH, Im Steingrund 4-6, 63303 Dreieich, Germany, klaus.schrickel@thermo.com

${ }^{3}$ Clausthaler Umwelttechnik-Institut-GmbH, Leibnizstraße 21 + 23, 38678 Clausthal-Zellerfeld, Germany,

hinnerk.bormann@cutec.de; michael.sievers@cutec.de

In this article the use of ozone for the treatment of pentylacetate contaminated waters is evaluated. Pentylacetate has started to be used in the drycleaning process as a new solvent due to its economic benefits. However, in the technical literature experimental data involving pentylacetate ozonation has not yet been reported. This article presents experimental results on the effect of $\mathrm{pH}$ on the rate of pentyalcetate removal by ozonation of contaminated waters. At acid $\mathrm{pH}$, pentylacetate is removed by a combination of single sparging and direct ozone reaction. As $\mathrm{pH}$ increases, the rate of pentylacetate removal also increases, showing the importance of free radical mechanism. The constant of indirect reaction rate for pentylacetate removal due to radicals is $2.6 \times 10^{9} \mathrm{M}^{-1} \mathrm{~S}^{-1}$.

Keywords: ozone, pentylacetate, reaction kinetics, wastewater treatment

\section{Introduction}

Textile care industry can generally be categorised into dry and wet cleaning. Such processes produce environmental concern. Wetcleaning is characterised by a high water consumption in combination with
En este artículo, se evalúa el uso del ozono para el tratamiento de aguas contaminadas con pentilacetato. El pentilacetato es un nuevo solvente que se ha comenzado a utilizar en el proceso de limpieza en seco de textiles, debido a sus beneficios económicos. Sin embargo, en la literatura técnica no existen datos experimentales registrados sobre ozonización de aguas contaminadas con pentilacetato. Este artículo presenta resultados experimentales del efecto del $\mathrm{pH}$ en la velocidad de eliminación de pentilacetato de aguas contaminadas a través de un proceso de ozonización. A pH ácido, el pentilacetato se elimina mediante una combinación de simple volatilización y reacción directa con el ozono molecular. Cuando el pH se incrementa, aumenta la velocidad de eliminación de pentilacetato, mostrando la importancia del mecanismo por radicales libres. La constante de velocidad de reacción para la eliminación indirecta del pentilacetato por acción de radicales es de 2,6 $\times 10^{9} \mathrm{M}^{-1} \mathrm{~s}^{-1}$.

Palabras clave: ozono, pentilacetato, cinética de reacciones, tratamiento de aguas residuals

specialised detergents and additives; while drycleaning uses predominantly non-aqueous solvents mainly perchloroethylene and hydrocarbon solvents (EPA, 1998; Kurz et al., 2001). In this respect, new technologies are necessary for solvent recycling and wastewater reuse as water process in order to reduce environmental impact. 
This paper approaches this topic and suggests the use of ozone in textile care industry for wastewater reclamation and reuse. Ozone is known by its capacity to oxidise complex organic compounds that are frequently present in effluents from textile industries and domestic laundries (Seo et al., 2001; Arslan et al., 2002). The reaction mechanism is a combination of direct oxidation where a selective attack of molecular ozone on double bonds takes place, and an indirect reaction involving non-selective freeradicals generated as a result of hydroxyl-induced ozone decomposition (Hoigné, 1998). In the case of complex effluents, such as wastewater generated during wetcleaning step after the drycleaning, there are compounds that can inhibit the action of free radicals reducing the intensity of the propagation reactions (e.g. sodium carbonate, scavengers, humectants, etc.).

Within this context, in this article the use of ozone for the treatment of pentylacetate contaminated waters is evaluated. Pentylacetate has started to be used in the drycleaning process as a new solvent due to its economic benefits. However, in the technical literature experimental data involving pentylacetate ozonation has not yet been reported. This paper addresses this issue, in particular, the effect of $\mathrm{pH}$ on pentylacetate removal rate and reaction mechanism, and reports the corresponding reaction rate constants with view to reactor design. This work was part of a wider innovative project that focused on technology development for water and solvent reclamation and reuse in the textile care industry (DBU, 2003).

\section{Experimental}

\section{Materials}

Pentylacetate (96\% purity) and all the chemicals used in this study were analytical reagent grade supplied by Merck. Tert-butyl alcohol ( $t$-BuOH) (> 99\% purity) was used as a radical scavenger since it reacts very rapidly with hydroxyl radicals $\left(k_{\cdot \mathrm{OH}, t-\mathrm{BuOH}}=5 \times 10^{8} \mathrm{M}^{-1} \mathrm{~s}^{-1}\right)$, but very slowly with ozone, $k_{\mathrm{O}, t-\mathrm{BuOH}}=0.03 \mathrm{M}^{-1} \mathrm{~s}^{-1}$ (Hoigné, 1998). Sodium 4-chlorobenzoate CBA ( $>98 \%$ purity) was used as a reference compound. All solutions were prepared with ultrapure water obtained from a Millipore MilliQ system. Ozone was produced from pure $\mathrm{O}_{2}$ supplied by Linde using an ozone generator (WEDECO Katadyn GmbH, Germany) rated at $25 \mathrm{gO}_{3} \mathrm{~h}^{-1}$ production.

\section{Experimental system}

Experiments were performed at laboratory scale, using a temperature-controlled reactor system based on a 2 $\mathrm{dm}^{3}$ stirred reactor and operated in a semi-batch mode (see Figure 1). pH values were adjusted to 2, 7, 9 using phosphoric acid or potassium phosphate buffer. The reactor temperature was set at $20 \pm 0.5{ }^{\circ} \mathrm{C}$. Typically, $5 \mathrm{dm}^{3} \mathrm{~min}^{-1}$ $\mathrm{O}_{3} / \mathrm{O}_{2}$ gas mixture was continuously fed to the reactor through a sparger. Initially, ozone gas was dissolved into pentylacetate-free buffered solution until ozone saturation was achieved. Then, a concentrated pentylacetate solution was injected into the mixture so that an initial concentration in the range $15 \times 10^{-6}-230 \times 10^{-6} \mathrm{M}$ was attained. Samples were taken periodically for further analysis; and $\mathrm{NaNO}_{2}$ was used to eliminate residual dissolved ozone.

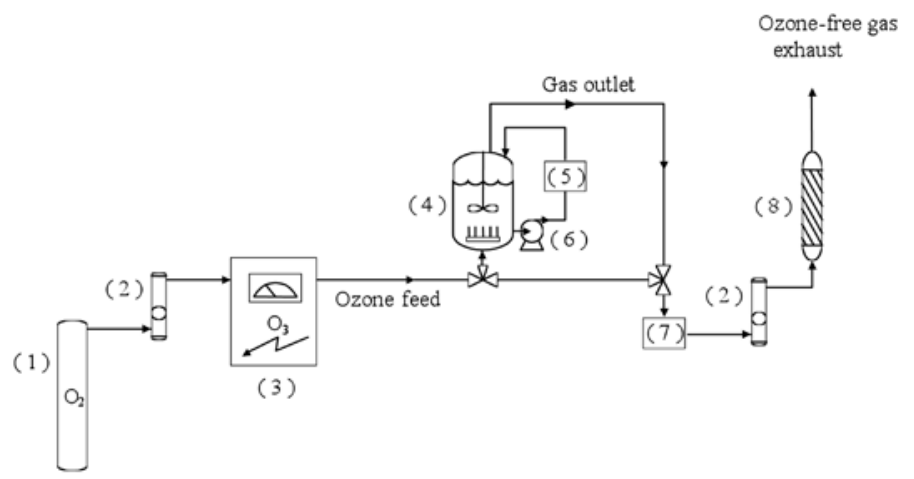

Figure 1: Experimental system: (1) Oxygen tank, (2) flowmeter, (3) ozone generator, (4) stirred tank reactor, (5) ozone liquid analyser, (6) liquid recirculation pump, (7) ozone gas analyser, (8) activated carbon trap.

\section{Analytical methods}

Inlet and outlet ozone gas concentrations were monitored using an ozone gas analyser (PCI-WEDECO, HC-500). Ozone concentration in aqueous solution was recorded online, using an ATI ozone analyser.

Pentylacetate was determined by gas chromatography using a GC-17A Shimadzu gas chromatograph, equipped with a capillary column (J\&W Scientific DB-WAX, 30 m length x $0.25 \mathrm{~mm}$ i.d., $0.5 \mu \mathrm{m}$ film thickness), a split injector and FID detector. A $23 \mathrm{~cm}^{3} \mathrm{~min}^{-1}$ flow of helium gas was used as carrier gas at $600 \mathrm{kPa}$. Split injections were conducted at 10:1 ratio and $18 \mathrm{~cm}^{3} \mathrm{~min}^{-1}$ flow. Prior to the injection, pentylacetate was extracted from ozonated samples using hexane at 1:1 ratio, during $60 \mathrm{~min}$. Separation started at 
$40^{\circ} \mathrm{C}$ and then the temperature was increased at $10^{\circ} \mathrm{Cmin}^{-1}$ to attain $240^{\circ} \mathrm{C}$ after $5 \mathrm{~min}$, using a constant flow rate of $1.7 \mathrm{~cm}^{3} \mathrm{~min}^{-1}$. After each separation, elution proceeded for further $2 \mathrm{~min}$ before the oven cold down and stabilises the column before next run. Data were stored and processed using a Shimadzu Class-up ${ }^{\text {TM }}$ V 4.3 automated software system.

Sodium 4-chlorobenzoate was determined by liquid chromatography. A Hewlett Packard 1050 model chromatograph was used, fitted with a Lichrospher ${ }^{\circledR} 100$ RP-18 $(5 \mu \mathrm{m})$ separating column. $10 \mu \mathrm{L}$ samples were injected and detection was carried out using a Shimadzu SPD-6A UV spectrophotometric detector at $234 \mathrm{~nm}$. Separation was performed with an acetonitrile- $\mathrm{NaH}_{2} \mathrm{PO}_{4}$ solution gradient, at $40^{\circ} \mathrm{C}$. A mixture of $5 \%$ acetonitrile and $95 \% 3 \mathrm{mM} \mathrm{NaH} \mathrm{PO}_{4}$ solution was used as solvent $\mathrm{A}$. Solvent B was prepared using a mixture of $70 \%$ acetonitrile and $30 \% 3 \mathrm{mM} \mathrm{NaH}_{2} \mathrm{PO}_{4}$ solution. Elution started with $2 \%$ $\mathrm{B}$ and then increased linearly to attain $100 \% \mathrm{~B}$ after 15 min, using a constant flow rate of $0.6 \mathrm{~cm}^{3} \mathrm{~min}^{-1}$. After $5 \mathrm{~min}$ at $100 \% \mathrm{~B}$, elution proceeded using $2 \% \mathrm{~B}$ for further 10 min, to stabilise the column before next injection.

\section{Results and discussion}

\section{Effect of $\mathrm{pH}$ on pentylacetate removal rate}

Figure 2 shows the pentylacetate PA dimensionless concentration as a function of ozonation time $\left(20{ }^{\circ} \mathrm{C}\right.$, $230 \times 10^{-6} \mathrm{M}$ initial PA concentration) under different $\mathrm{pH}$ conditions ( $\mathrm{pH} 2-9$ ) and in absence of radical scavengers. Dimensionless concentrations were calculated as a fraction of initial PA concentration.

As seen in Figure 2, the PA removal rate increased with $\mathrm{pH}$. Indeed, the PA removal rate increased around $80 \%$ as $\mathrm{pH}$ raised from 2 to 9 . All PA was removed after 20 min ozonation at $\mathrm{pH} 9$, as compared with more than 60 min required at $\mathrm{pH} 2$. At acid $\mathrm{pH}, \mathrm{PA}$ is eliminated by a combination of stripping and direct ozone reaction with a pseudo-first order kinetic rate constant of $0.7 \times 10^{-3} \mathrm{~s}^{-1}$; while at $\mathrm{pH} 9 \mathrm{PA}$ the pseudo-first order kinetic rate constant is increased to $3.5 \times 10^{-3} \mathrm{~s}^{-1}$. At basic $\mathrm{pH}$, the increase in the PA removal rate was due to PA reaction with hydroxyl radicals coming from ozone aqueous decomposition.

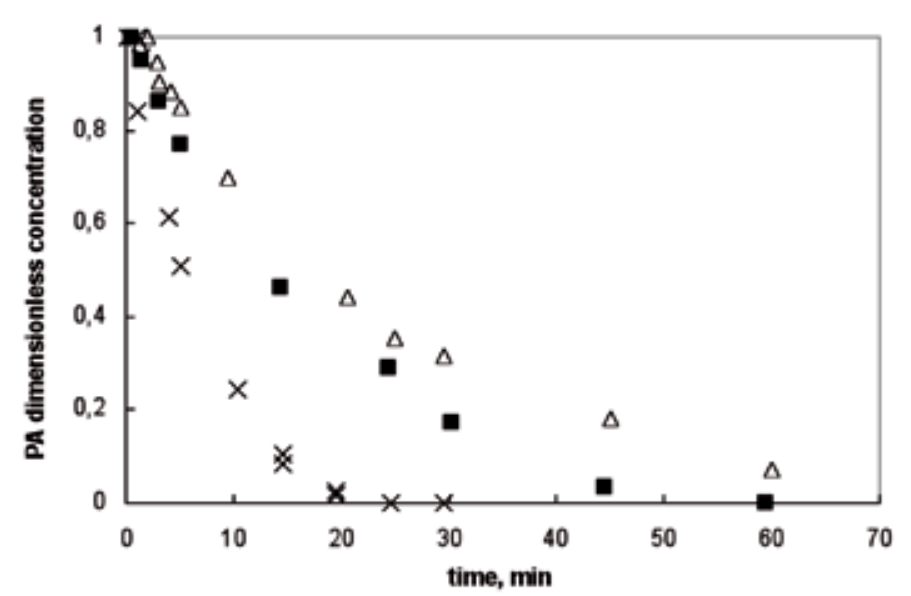

Figure 2: Ozonation of PA. Influence of $\mathrm{pH}: \Delta \mathrm{pH}=2, \boldsymbol{\sim} \mathrm{pH}=7$, $\mathrm{x} \mathrm{pH}=9$.

\section{Kinetic modelling}

PA removal rate by ozonation in water could be described by a simplified and unbalanced reaction mechanism as follows:

Sparging:

$\mathrm{PA}_{(\mathrm{aq})} \rightarrow \mathrm{PA}_{(\mathrm{g})}$

$$
-\frac{d C_{P A}}{d t}=r_{S}=k_{S} C_{P A}
$$

Direct reaction:

$$
\mathrm{O}_{3(\mathrm{aq})}+\mathrm{PA}_{(\text {aq) }} \rightarrow \text { products }-\frac{d C_{P_{A}}}{d t}=r_{D}=k_{D} C_{P A} C_{O 3}
$$

Indirect reaction:

$$
{ }^{\circ} \mathrm{OH}_{(\mathrm{aq})}+\mathrm{PA}(\mathrm{aq}) \rightarrow \text { products } \quad-\frac{d C_{P_{A}}}{d t}=r_{I}=k_{I} C_{P A} C_{\cdot \mathrm{OH}}
$$

The total rate of PA removal could then be represented as a linear combination of terms representing sparging and ozonation:

$$
-\frac{d C_{P A}}{d t}=r_{S}+r_{D}+r_{I}=k_{S} C_{P A}+k_{D} C_{P A} C_{O 3}+k_{I} C_{P A} C_{\bullet \text { OH }}
$$

where, $r_{S}, r_{D}$ and $r_{I}$ represent the removal rate due to sparging, direct and indirect ozone reactions, respectively. $C_{P A}, C_{O 3}$, and $C_{. O H}$ are the species concentrations; $k_{S}$ is the sparging removal rate constant; $k_{D}$ and $k_{I}$ represent the second-order rate constants for PA reaction with $\mathrm{O}_{3}$ and -OH radicals, respectively. 


\section{Direct reaction kinetics}

Figure 3 presents the corresponding linearised plot for data obtained at $\mathrm{pH} 2$, in presence of $t-\mathrm{BuOH}(0.01 \mathrm{M})$; conditions where the direct reaction mechanism prevailed.

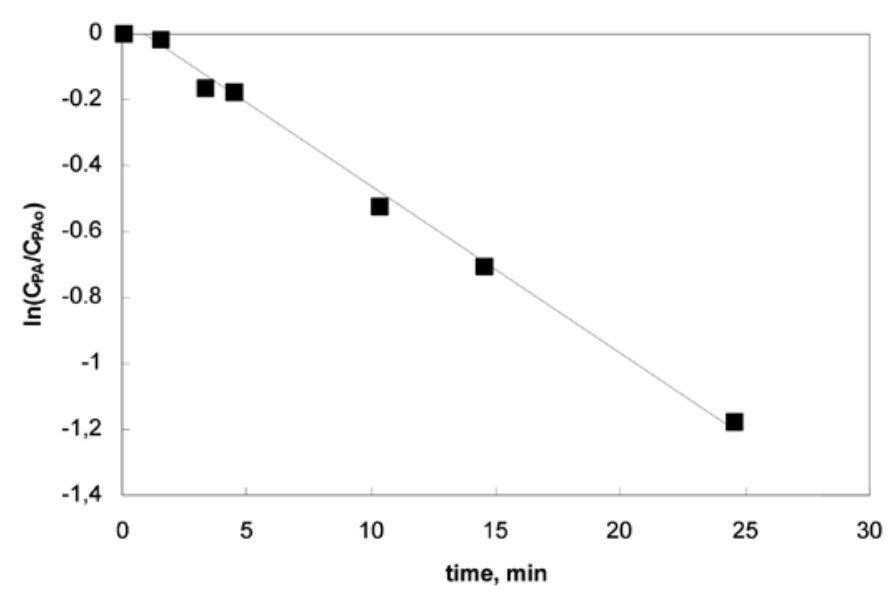

Figure 3: Determination of direct reaction constant between $\mathrm{O}_{3}$ and $\mathrm{PA}$ in aqueous phase. $\mathrm{pH} 2,20^{\circ} \mathrm{C}, 0.01 \mathrm{M} t$-BuOH.

Experimental points fitted well a linear pseudo-first order model, with correlation coefficients above 0.99. The second-order direct reaction rate constant, $k_{D}$, at $20^{\circ} \mathrm{C}$ was $2.7 \mathrm{M}^{-1} \mathrm{~s}^{-1}$.

\section{Indirect reaction kinetics}

Indirect rate constant of the reaction between PA and hydroxyl radicals, was determined at $\mathrm{pH} 9$, in absence of free radicals scavengers and without sparging, at $20^{\circ} \mathrm{C}$. Sodium 4-chlorobenzoate CBA was used as a probe compound, whose constant rate with hydroxyl radicals is known, $k_{I, C B A}=4.4 \times 10^{9} \mathrm{M}^{-1} \mathrm{~s}^{-1}$ (Hoigné, 1997). Both, PA as well as CBA reactions with hydroxyl radicals are described by means of second order kinetics:

$$
\begin{aligned}
& -\frac{d C_{P A}}{d t}=k_{I, P A} C_{\bullet O H} C_{P A} \\
& -\frac{d C_{C B A}}{d t}=k_{I, C B A} C_{\bullet O H} C_{C B A}
\end{aligned}
$$

where, $k_{I, P A}$ and $k_{I, C B A}$ represent intrinsic rate constants of hydroxyl radical reactions of PA and CBA, respectively. By dividing the equations (5) and (6) and by integrating the expression that relates rate constants to solute concentration variations during reaction yields:

$$
\ln \frac{\mathrm{C}_{\mathrm{CBA}}}{\mathrm{C}_{\mathrm{CBA}_{0}}}=\frac{\mathrm{k}_{\mathrm{I}, \mathrm{CBA}}}{\mathrm{k}_{\mathrm{I}, \mathrm{PA}}} \ln \frac{\mathrm{C}_{\mathrm{PA}}}{\mathrm{C}_{\mathrm{PA}_{0}}}
$$

Experiments were carried out with different initial concentrations ratio $C_{C B A o}: C_{P A O}(1: 1,1: 3,3: 1)$. Figure 4 shows experimental results, according to equation (7).

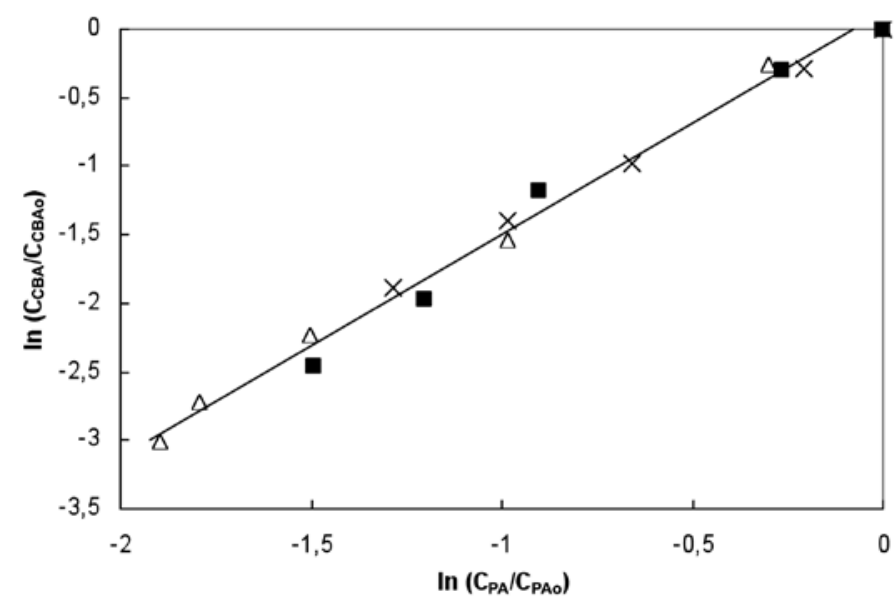

Figure 4: Determination of indirect reaction constant. $C_{C B A \circ}: C_{P A O}$ initial concentrations ratio: $\times 1: 1, \Delta 1: 3, \mathbf{n} 3: 1$.

Data fitted quite well the linealised model with a correlation coefficient above 0.99 . The rate constant of second order indirect reaction between hydroxyl radicals and pentylacetate, $k_{I, P A}$, at $20^{\circ} \mathrm{C}$ was $2.6 \times 10^{9} \mathrm{M}^{-1} \mathrm{~s}^{-1}$, which is smaller than indirect reaction rate constants reported for other researchers using different organic model compounds (Sánchez-Polo et al., 2002; Valdés et al., 2003).

\section{Conclusions}

This study shows that PA could be effectively removed using ozone at basic $\mathrm{pH}$. Experimental results show that ozone treatment removes PA from contaminated waters by a combined mechanism. At acid $\mathrm{pH}$, pentylacetate is eliminated by a combination of stripping and direct ozone reaction with a pseudofirst order kinetic rate constant of $0.7 \times 10^{-3} \mathrm{~s}^{-1}$; while at $\mathrm{pH} 9$ pseudofirst order kinetic rate constant of PA is increased to $3.5 \times 10^{-3} \mathrm{~s}^{-1}$. At basic $\mathrm{pH}$, PA is oxidised by hydroxyl radicals coming from ozone aqueous decomposition. The overall rate of the indirect reaction between ozone and pentylacetate could be approximated to a second order kinetic model with a rate constant at $20^{\circ} \mathrm{C}$ 
of $2.6 \times 10^{9} \mathrm{M}^{-1} \mathrm{~s}^{-1}$. The radical reaction contribution at $\mathrm{pH}$ 9 accounts for $80 \%$ PA removal rate. This is a key issue regarding process design, since free radical scavengers, such as carbonates, may be present in water and affect the PA removal efficiency.

\section{Acknowledgements}

The authors wish to thank the DBU Projekt "Entwicklung von Verfahren und Maschine zur Nassreinigung und Trocknung von Textilien" for their financial support. In addition, the first author expresses his gratitude to the Deutscher Akademischer Austausch Dienst (DAAD) for providing a post-doctoral research fellowship.

\section{References}

Arslan, I., Akmehmet, I.B. and Bahnemann, D.W. (2002). Advanced oxidation of a reactive dyebath effluent: comparison of $\mathrm{O}_{3}, \mathrm{H}_{2} \mathrm{O}_{2} / \mathrm{UV}-\mathrm{C}$ and $\mathrm{TiO}_{2} / \mathrm{UV}-\mathrm{A}$ processes. Water Research 36, $1143-1154$.

DBU Deutschen Bundesstiftung Umwelt (2003). Projekt: Entwicklung eines Verfahrens und einer Reinungsmaschine zur Nassreinigung und Trocknung von Textilien.
EPA (1998). Cleaner technologies substitutes' assessment: professional fabricare processes. Design for the environment U.S. Environmental Protection Agency Ed. EPA 744-B-98-001.

Kurz, J., Gosolits, B. and Tagge, J. (2001). In ATV-Handbuch Industrieabwasser. Dienstleistungs- und Veredelungsindustrie. Chapter 13. Ernst \& Sohn.

Hoigné, J. (1998). In Hrubec (ed.), The Handbook of Environmental Chemistry. Vol. 5. Part C. Quality and Treatment of Drinking Water II. Berlin: Springer-Verlag.

Hoigné, J. (1997). Inter-calibration of OH radical sources and water quality parameters. Water Science and Technology 35, 1-8.

Sánchez-Polo, M., Rivera-Utrilla, J., Mondaca, M.A. and Zaror. C.A. (2002). Effect of ozone and ozone/activated carbon treatments on genotoxic activity of naphtalenesulfonic acids. Journal of Chemical Technology \& Biotechnology 77, 883-890.

Seo, G.T., Lee, T.S., Moon, B.H. and Lim. J.H. (2001). Ultrafiltration combined with ozone for domestic laundry wastewater reclamation and reuse. Water Science and Technology: Water Supply 1, 387-392.

Valdés, H., Zaror, C.A. and Jekel, M. (2003). Kinetic study of reactions between ozone and benzothiazole in water. Water Science and Technology 48, 505-510. 